\title{
Preeklamsia Pascasalin
}

\author{
Nuswil Bernolian, Wim T. Pangemanan, A. Kurdi Syamsuri, M. Hatta Ansyori, \\ Putri Mirani, Peby Maulina Lestari, Abarham Martadiansyah, Cindy Kesty \\ Divisi Fetomaternal KSM/Bagian Obstetri dan Ginekologi \\ RSUP dr. Mohammad Hoesin Palembang Fakultas Kedokteran Universitas Sriwijaya \\ Korespondensi:Nuswil Bernolian, Email: nuswilbernoli@gmail.com
}

\begin{abstract}
Abstrak
Tujuan untuk memaparkan etiologi dan faktor risiko, diagnosis banding, patofisiologi, pemantauan, terapi, komplikasi, rekurensi dan tindakan preventif pada kasus preeklamsia pascasalin. Metode tinjauan pustaka dengan berbagai referensi yang diakses melalui mesin pencarian seperti Pubmed dan Sci-Hub dengan menggunakan kata kunci preeclampsia, hypertension, postpartum, management. Sumber referensi yang digunakan yaitu guidelines, jurnal, dan buku teks yang diterbitkan dalam 15 tahun terakhir. Kesimpulan, insiden preeklamsia di Indonesia yaitu 128.273/tahun atau sekitar 5,3\%. Sebanyak 0,3 - 27,5\% kasus yang dilaporkan mengalami preeklamsia atau hipertensi pascasalin. Gejala-gejala preeklamsia pascasalin muncul setelah melahirkan. Mayoritas kasus berkembang dalam 48 jam setelah persalinan, walaupun sindrom dapat muncul hingga 6 minggu setelah persalinan. Periode pascasalin merupakan waktu kritis bagi spesialis obstetri dan ginekologi untuk menjamin wanita dengan riwayat preeklamsia untuk dipantau dalam jangka waktu pendek dan panjang. Akan tetapi, pemantauan pascasalin sangatlah rendah, berkisar antara 20-60\%. Pemilihan antihipertensi pasca salin yaitu berikatan kuat dengan protein dan solubilitas lipid yang rendah sehingga lebih sedikit yang masuk ke ASI. Selain itu, dipengaruhi juga oleh ionisasi, berat molekul dan konstituen ASI (kandungan lemak, protein, dan air). Agen lini pertama untuk preeklamsia pascasalin adalah labetalol dan hidralazin intravena serta nifedipin. Wanita dengan hipertensi gestasional ataupun preeklamsia biasanya dapat menghentikan antihipertensi dalam 6 minggu pasca salin.
\end{abstract}

Kata kunci: preeklamsia pascasalin, antihipertensi

\section{Postpartum Preeclampsia}

\begin{abstract}
Objective: To explain about etiologies and risk factors, differential diagnosis, pathophysiology, follow up, treatment, complications, recurrence, and prevention of preeclampsia post delivery discharged. Method literature review with several references accessed through search engines such as Pubmed and Sci-Hub by using keywords preeclampsia, hypertension, postpartum, management. Reference sources used are guidelines, journals, and textbooks published in the last 15 years. Conclusion the incidence of preeclampsia in Indonesia is 128,273/year or around 5.3\%. As many as 0.3-27.5\% of cases reported postpartum preeclampsia or hypertension. Symptoms of postpartum preeclampsia appear after delivery. The majority of cases develop within 48 hours after delivery, although the syndrome can appear up to 6 weeks after delivery. The postpartum period is a critical time for obstetricians and gynecologists to ensure women with a history of preeclampsia are monitored in the short and long term. However, postpartum monitoring is very low, ranging from 20-60\%. The choice of antihypertensive postpartum is that it is strongly bound to protein with low lipid solubility so that fewer enter breast milk. In addition, it is also influenced by ionization, molecular weight and constituents of breast milk (fat content, protein, and water). The first line agent for postpartum preeclampsia is intravenous labetolol and hydralazine and also nifedipine. Women with gestational hypertension or preeclampsia can usually stop antihypertension within 6 weeks postpartum.
\end{abstract}

Key word: postpartum preeclampsia, antihypertension 


\section{Pendahuluan}

World Health Organization (WHO) memperkirakan kasus preeklamsia tujuh kali lebih tinggi di negara berkembang daripada di negara maju. Prevalensi di negara berkembang adalah 1,8\%-18\%. Insiden preeklamsia di Indonesia sendiri adalah 128.273/tahun atau sekitar 5,3\%. Adapun sebanyak $0,3-27,5 \%$ kasus yang dilaporkan mengalami preeklamsia atau hipertensi pascasalin. ${ }^{1-2}$ Tiga studi kohort prospektif di United Kingdom (UK) menunjukkan 32 $44 \%$ kasus eklamsia terjadi pasca salin. ${ }^{1-11}$

Pada serial kasus dari 28 wanita dengan preeklamsia dengan gejala berat dan stroke, satu wanita mengalami hipertensi sistolik berat sebelum stroke hemoragik dan 54\% meninggal, dan hanya $13 \%$ mengalami hipertensi diastolik dalam beberapa jam sebelum stroke. Wanita yang mengalami hipertensi selama hamil dapat menjadi normotensi setelah persalinan tetapi dapat pula menjadi hipertensi kembali dalam minggu pertama pascasalin Mayoritas kasus berkembang dalam 48 jam setelah persalinan, walaupun sindrom dapat muncul hingga 6 minggu setelah persalinan.2,3 Di sisi lain, kontrol hipertensi selama perawatan dapat menunda pemulangan pasien. 4

American HeartAssociation (AHA) barubaru ini menyimpulkan bahwa preeklamsia merupakan faktor risiko kardiovaskuler poten, selain diabetes melitus. Salah satu faktor risikonya yaitu hipertensi persisten pada periode pascasalin. Periode pascasalin merupakan waktu kritis bagi spesialis obstetri dan ginekologi untuk menjamin wanita dengan riwayat preeklamsia untuk dipantau dalam jangka waktu pendek dan panjang.

Pemantauan jangka panjang sangat penting karena wanita dengan riwayat preeklamsia berisiko tinggi untuk mengalami penyakit jantung ke depannya, namun demikian pemantauan pascasalin sangatlah rendah, berkisar antara $20-60 \% .^{4}$ Tujuan tinjauan pustaka ini adalah memaparkan definisi, faktor risiko, cara diagnosis, tatalaksana, komplikasi dan tindakan preventif pada kasus preeklamsia pasca salin.

\section{Metode}

Penulis memaparkan tinjauan pustaka dengan berbagai referensi yang diakses melalui mesin pencarian seperti Pubmed dan Sci-Hub dengan menggunakan kata kunci preeclampsia, hypertension, postpartum, management. Sumber referensi yang digunakan yaitu guidelines, jurnal, dan buku teks yang diterbitkan dalam 15 tahun terakhir.

\section{Etiologi dan Faktor Risiko Preeklamsia Pascasalin}

Vasodilatasi sistemik generalisata terjadi selama kehamilan walaupun terdapat $40-50 \%$ peningkatan output jantung, Mean Arterial Pressure (MAP) menurun sebesar $10 \mathrm{mmHg}$ untuk mencapai nilai terendahnya pada tengah kehamilan. Selama trimester akhir, tekanan darah meningkat secara perlahan mencapai nilai sebelum hamil. Tekanan darah biasanya menurun setelah persalinan, akan meningkat mencapai puncak 3-6 hari pascasalin pada wanita dengan tekanan darah normal dan hipertensi selama kehamilan. Hipertensi transien dapat terjadi pascasalin setelah kehamilan tanpa komplikasi. Kondisi ini dapat terjadi sekunder terhadap nyeri, obatobatan, pemberian cairan berlebihan, garam dan air yang terakumulasi selama kehamilan, pindah ke kompartemen intravaskuler atau menjaga tonus vaskuler pada kondisi tidak hamil.

Tekanan darah yang meningkat biasanya akan menjadi normal beberapa hari pascasalin (29-57\% dalam 3 hari; $50-85 \%$ dalam 7 hari) pada mayoritas wanita, dengan kecepatan resolusi dan prevalensi hipertensi persisten tergantung pada diagnosisnya. Proporsi wanita yang tetap mengalami hipertensi 
Tabel 1 Etiologi/Diagnosis Banding Hipertensi Pascasalin

\begin{tabular}{|c|c|}
\hline Etiologi & Temuan Penting \\
\hline Hipertensi-preeklamsia onset baru & Onset 3-6 hari pasca salin tanpa sakit kepala \\
\hline Kelebihan volume & Volume cairan yang besar, anestesi regional, mobilisasi terlambat \\
\hline Obat-obatan & OAINS, derivat ergot \\
\hline Ibuprofen, indometasin & Vasokonstriksi periferal dan serebral, sakit kepala \\
\hline Fenilpropanolamin, efedrin & Vasokonstriksi periferal dan serebral, sakit kepala \\
\hline Ergotamin, ergonovin & Vasokonstriksi, sakit kepala, mual, muntah, kejang \\
\hline $\begin{array}{l}\text { Persistensi preeklamsia- hipertensi } \\
\text { gestasional }\end{array}$ & Kondisi antepartum atau inpartu yang mendasarinya \\
\hline Eklamsia onset lambat & Sakit kepala, perubahan visual, kejang, tidak ada defisit neurologis \\
\hline Sindrom HELLP & $\begin{array}{l}\text { Mual/muntah, nyeri epigastrium, trombosit rendah, enzim hati } \\
\text { meningkat }\end{array}$ \\
\hline $\begin{array}{l}\text { Hipertensi yang tidak terdiagnosis } \\
\text { atau sudah ada sebelumnya }\end{array}$ & Hipertensi sebelum kehamilan, atau $<20$ minggu \\
\hline Penyakit ginjal sebelumnya & Proteinuria atau hematuria $<20$ minggu \\
\hline Hipertiroidisme & Takikardia palpitasi, berkeringat, kulit kering, gagal jantung \\
\hline Hiperaldosteronisme primer & Hipertensi refrakter, hipokalemia, alkalosis metabolik \\
\hline Feokromositoma & Hipertensi paroksismal, sakit kepala, nyeri dada, hiperglikemia \\
\hline Stenosis arteri renalis & Hipertensi yang refrakter terhadap terapi \\
\hline Sindrom vasokonstriksi serebral & Nyeri kepala hebat dan tiba-tiba, perubahan visual, defisit neurologis \\
\hline Trombosis vena serebral/stroke & Onset 3-7 hari, sakit kepala perlahan atau akut, kejang, defisit neurologis \\
\hline $\begin{array}{l}\text { Purpura trombositopenia trombotik/ } \\
\text { sindrom uremik hemolitik }\end{array}$ & Hemolisis, trombositopenia berat, gejala neurologis, enzim hati normal \\
\hline
\end{tabular}

dalam 6-12 minggu pascasalin tergantung pada populasi. Wanita dengan hipertensi kronik sebelumnya, pemberian antihipertensi selama kehamilan dalam durasi lama, tekanan darah sistolik dan diastolik maksimum yang lebih tinggi, Indeks Massa Tubuh (IMT) yang lebih tinggi, dan preeklamsia preterm lebih mungkin untuk mengalami hipertensi berkelanjutan. ${ }^{1}$ Kelompok yang berisiko mengalami hipertensi persisten yaitu wanita dengan obesitas morbid, didiagnosis preeklamsia dengan gejala berat berdasarkan kriteria tekanan darah, dan wanita yang dipulangkan dengan obat antihipertensi. ${ }^{4}$

\section{Diagnosis Banding}

Etiologi dan diagnosis banding hipertensi pasca alin bervariasi dan dapat berfokus pada temuan klinis dan laboratorium serta respon terhadap terapi tekanan darah (Tabel 1). ${ }^{6}$

\section{Patofisiologi}

Patofisiologi preeklamsia dan eklamsia diringkas pada Gambar 1. Patofisiologi preeklamsia belum dapat dijelaskan secara pasti. Penyebab pasti penyakit ini adalah kegagalan invasi trofoblas yang menyebabkan kegagalan transformasi arteri spiralis dan plasentasi dalam yang tidak tepat. Selain itu, etiologi lainnya yaitu ekspresi abnormal dari antigen permukaan sel Natural Killer (NK) dan kegagalan regulasi sitotoksisitas sel NK dan faktor sitokin atau angiogenesis sehingga menyebabkan aliran yang tinggi dan tekanan 
darah tinggi. Hal ini dapat menyebabkan iskemia plasenta sehingga membentuk radikal oksigen reaktif dan disfungsi endotel lanjut.

Selain itu, teori imbalans angiogenik berupa soluble fms-like tyrosine kinase (sFlt-1) atau endoglin yang berlebihan dan placental growth factor (PIGF) yang berkurang. ${ }^{7}$ Selain itu, beberapa wanita dengan preeklamsia memiliki autoantibodi terhadap reseptor antiotensin II tipe 1 (AT1) pada serum sehingga dapat mengaktivasi AT1 di sel endotel, sel otot polos vaskuler, dan sel mesangial dari glomerulus.

Autoantibodi AT1 dapat menyebabkan hipertensi, proteinuria, endoteliosis kapiler glomerulus, peningkatan produksi s VEGFR-1 (soluble Vascular Endothelial Growth Factor Receptor) dan sEng (soluble Endoglin) serta menstimulasi sintesis NADPH (Nicotinamide Adenine Dinucleotide Phosphate) oksidase. Beberapa faktor ini menyebabkan stres oksidatif, peningkatan trombin, defek fibrinolisis dengan deposit fibrin sehingga menyebabkan suatu keadaan antiangiogenik. Beberapa faktor lain seperti genetik, lingkungan, dan gaya hidup juga berperan dalam patofisiologi preeklamsia. ${ }^{7}$

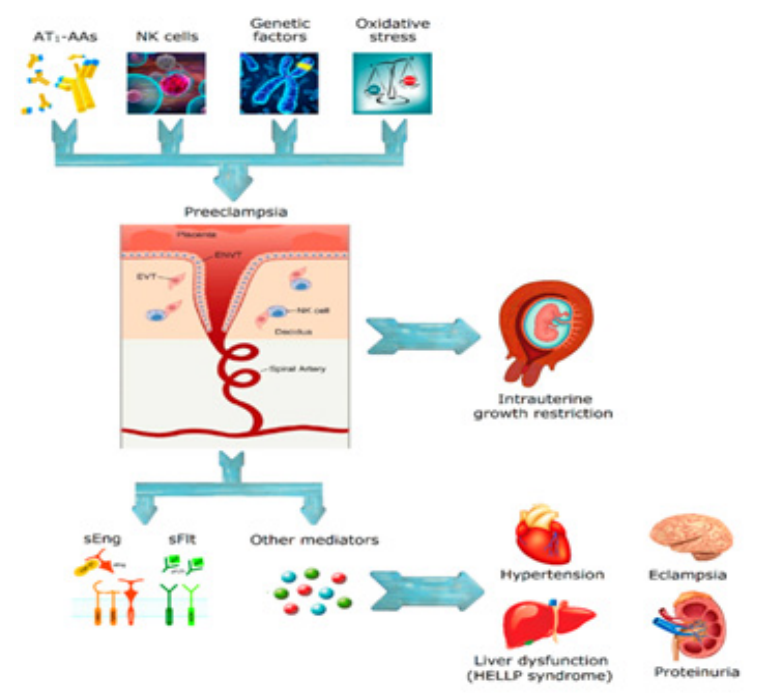

Gambar 1 Patofisiologi Preeklamsia dan Eklamsia.

Dikutip dari: Peres GM et al, 2018. ${ }^{7}$

\section{Pemantauan}

Panduan NICE merekomendasikan pemantauan TD pascasalin rutin untuk wanita dengan preeklamsia (setiap 1-2 jam selama 2 minggu) dan hipertensi gestasional (setidaknya 1 kali antara hari ke-3 dan 5), perawatan rutin pascasalin merekomendasikan pemeriksaan tekanan darah dalam 6 jam pasca salin pada semua wanita normotensi tanpa komplikasi kehamilan. ${ }^{1,3}$

Mereka juga merekomendasikan pemeriksaan tekanan darah pada hari kelima pasca salin untuk mengidentifikasi wanita dengan preeklamsia onset lambat.

Pemeriksaan proteinuria pasca salin tidak direkomendasikan karena terdapat lokia. Panduan NICE untuk manajemen hipertensi dalam kehamilan merekomendasikan untuk menginformasikan semua wanita mengenai kemungkinan hipertensi, preeklamsia, atau eklamsia dan memberikan informasi mengenai gejala-gejala relevan seperti sakit kepala hebat (peningkatan frekuensi dan tidak membaik dengan analgesia reguler), gangguan penglihatan seperti pandangan kabur, melihat cahaya, diplopia atau bintik melayang, mual dan muntah, malaise, sesak nafas akibat edema paru, edema muka, tangan atau kaki secara tiba-tiba, kejang hingga 4 minggu pascasalin. ${ }^{1}$

The American College of Obstetricians and Gynecologists (ACOG) merekomendasikan pemantauan tekanan darah (TD) di RS selama 72 jam pascasalin dan diperiksa kembali 7-10 hari pascasalin (lebih cepat jika wanita memiliki gejala). ACOG menyarankan untuk terapi jika $\geq$ 150/100 mmHg, setidaknya 2 kali pengukuran dengan interval 4-6 jam. Pemberian aspirin sebagai profilaksis pada wanita berisiko tinggi sebelum usia kehamilan 16 minggu dapat mengurangi risiko preeklamsia sebesar $17 \%$. Selain itu, terdapat pengurangan risiko relatif sebesar $8 \%$ dari persalinan preterm dan 
pengurangan kematian janin dan neonatus sebesar $14 \% .9$

\section{Terapi Preeklamsia Pascasalin}

Tujuan terapi hipertensi berat adalah untuk mencegah gagal jantung kongestif, iskemia miokardium, cedera atau gagal ginjal, dan stroke iskemik atau hemoragik. Terapi antihipertensi sebaiknya dimulai sesegera mungkin untuk hipertensi berat onset akut (tekanan darah sistolik $160 \mathrm{mmHg}$ atau lebih atau tekanan darah diastolik 110 $\mathrm{mmHg}$ atau lebih atau keduanya). Literatur menunjukkan agen antihipertensi sebaiknya diberikan dalam 30-60 menit. Namun, terapi antihipertensi sebaiknya diberikan sesegara mungkin setelah kriteria hipertensi berat onset akut terpenuhi. Hidralazin atau labetalol intravena atau nifedipin oral merupakan tiga agen yang paling sering digunakan. Labetalol oral dan penghambat kanal kalsium biasanya digunakan, diberikan labetalol $200 \mathrm{mg}$ setiap 12 jam secara oral dan meningkatkan dosis hingga $800 \mathrm{mg}$ setiap $8-12$ jam secara oral jika dibutuhkan (dosis maksimum $2.400 \mathrm{mg} /$ hari). Jika dosis maksimum tidak cukup untuk mencapai target tekanan darah, atau dosis dibatasi karena efek samping, lalu nifedipin oral kerja pendek dapat ditambahkan secara

Tabel 2 Dosis Obat-obatan untuk Ibu Menyusui ${ }^{10}$

\begin{tabular}{|c|c|c|}
\hline Obat & Dosis & Keterangan \\
\hline \multicolumn{3}{|c|}{ Direkomendasikan oleh National Institute for Health and Clinical Excellence (NICE) dan digunakan secara luas di Inggris } \\
\hline \multicolumn{3}{|c|}{ Penghambat alfa/beta } \\
\hline Labetalol & $100-600 \mathrm{mg}$ 2-3 kali sehari & Hanya sejumlah kecil terdeteksi pada Air Susu Ibu (ASI) \\
\hline Atenolol & 25-100 mg sekali sehari & $\begin{array}{l}\text { Penggunaan lini kedua pada wanita yang memerlukan for- } \\
\text { mula sekali sehari }\end{array}$ \\
\hline \multicolumn{3}{|c|}{ Penghambat kanal kalsium } \\
\hline $\begin{array}{l}\text { Nifedipin lepas } \\
\text { lambat }\end{array}$ & $10-20$ mg 2 kali sehari & $\begin{array}{l}\text { Jumlah pada ASI sangat sedikit yang dapat membahay- } \\
\text { akan; produsen menyarankan sebaiknya dihindari tetapi } \\
\text { telah digunakan secara luas tanpa laporan mengenai efek } \\
\text { samping pada neonatus }\end{array}$ \\
\hline Amlodipin & 5-10 mg sekali sehari & Penggunaan lini kedua pada wanita yang memerlukan for- \\
\hline $\begin{array}{l}\text { Nifedipin lepas } \\
\text { moderat }\end{array}$ & $30-60 \mathrm{mg}$ sekali sehari & $\begin{array}{l}\text { mula sekali sehari; jumlah pada ASI sangat sedikit yang } \\
\text { dapat membahayakan; produsen menyarankan sebaiknya } \\
\text { obat dihindari tetapi telah digunakan pada praktik klinis } \\
\text { tanpa laporan mengenai efek sampingnya }\end{array}$ \\
\hline \multicolumn{3}{|c|}{ Penghambat Angiotensin Converting Enzyme (ACE) } \\
\hline Enalapril & $5-20$ mg 2 kali sehari & $\begin{array}{l}\text { Dapat digunakan pada wanita yang sebelumnya mengon- } \\
\text { sumsi penghambat ACE ketika agen pilihan pertama lain- } \\
\text { nya tidak dapat digunakan atau proteksi jantung/ginjal di- } \\
\text { perlukan; diekskresikan pada ASI dalam kadar rendah tapi } \\
\text { jumlahnya mungkin sedikit untuk dapat berbahaya }\end{array}$ \\
\hline \multicolumn{3}{|l|}{ Kontraindikasi } \\
\hline $\begin{array}{l}\text { Penghambat } \mathrm{ACE} \\
\text { atau reseptor } \\
\text { angiotensin lainnya }\end{array}$ & Tidak direkomendasikan & $\begin{array}{l}\text { Terdapat sedikit data mengenai penggunaannya selama } \\
\text { laktasi; produsen menyarankan sebaiknya dihindari }\end{array}$ \\
\hline Diuretik & Tidak direkomendasikan & $\begin{array}{l}\text { Memproduksi rasa haus berlebih pada wanita yang me- } \\
\text { nyusui; dosis besar dapat menghambat laktasi }\end{array}$ \\
\hline
\end{tabular}


perlahan. ${ }^{10}$

Pemilihan antihipertensi pascasalin yaitu berikatan kuat dengan protein dan solubilitas lipid yang rendah sehingga lebih sedikit yang masuk ke ASI. Selain itu, dipengaruhi juga oleh ionisasi, berat molekul dan konstituen ASI (kandungan lemak, protein, dan air). Ibu yang menyusui bayi yang lahir preterm sebaiknya diterapi oleh dokter subspesialis perinatologi. NICE merekomendasikan bahwa metildopa diganti ke obat lain karena berhubungan dengan sedasi, hipertensi postural, dan depresi. Akan tetapi, Medicines and Healthcare Products Regulatory Agency (MHRA) mempertimbangkan metildopa sebagai obat pilihan selama menyusui. Untuk wanita berkulit hitam dari suku Afrika atau Caribbean, dimana renin plasma rendah pada usia muda, penghambat kanal kalsium seperti nifedipin merupakan pilihan dan Angiotensin Converting Enzyme (ACE) inhibitor sebagai lini kedua karena penghambat beta kurang bermanfaat pada kelompok wanita ini. Walaupun ACE inhibitor dan Angiotensin
Receptor Blockers (ARB) kontraindikasi dalam kehamilan, enalapril dapat digunakan secara aman pada wanita yang menyusui. ${ }^{1,11}$

Berdasarkan penelitian dari James dan Piercy (2004), agen lini pertama untuk preeklamsia pascasalin adalah atenolol ditambah nifedipin atau penghambat ACE. Wanita dengan hipertensi gestasional ataupun preeklamsia biasanya dapat menghentikan antihipertensi dalam 6 minggu pascasalin. Wanita dengan hipertensi kronik dapat menggunakan obat-obatan sebelum kehamilan. Diuretik biasanya dihindari pada wanita yang menyusui karena akan meningkatkan rasa haus. Proteinuria pada wanita preeklamsia dapat membaik dalam 3 bulan pasca salin, jika tidak ada abnormalitas ginjal lainnya. ${ }^{11}$

Tinjauan Cochrane mengidentifikasi tidak ada percobaan yang membandingkan terapi obat antihipertensi dengan plasebo untuk wanita dengan hipertensi pascasalin ringan hingga sedang.

Namun, tiga percobaan (189 wanita)

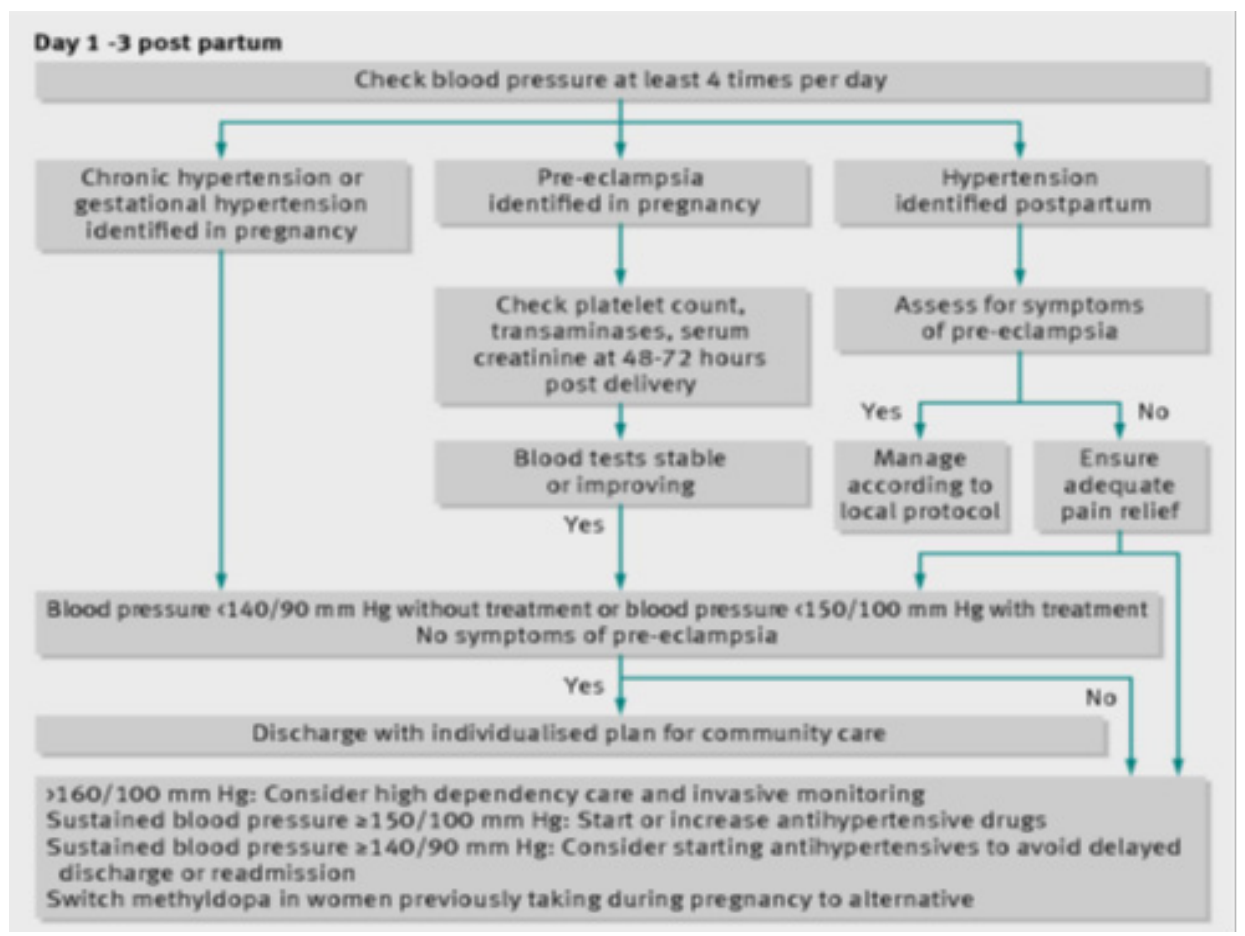

\section{Bagan 1 Terapi Rawat Inap pada Hipertensi Pascasalin}

Dikutip dari: Bramham K et al, 2013. ${ }^{1}$ 


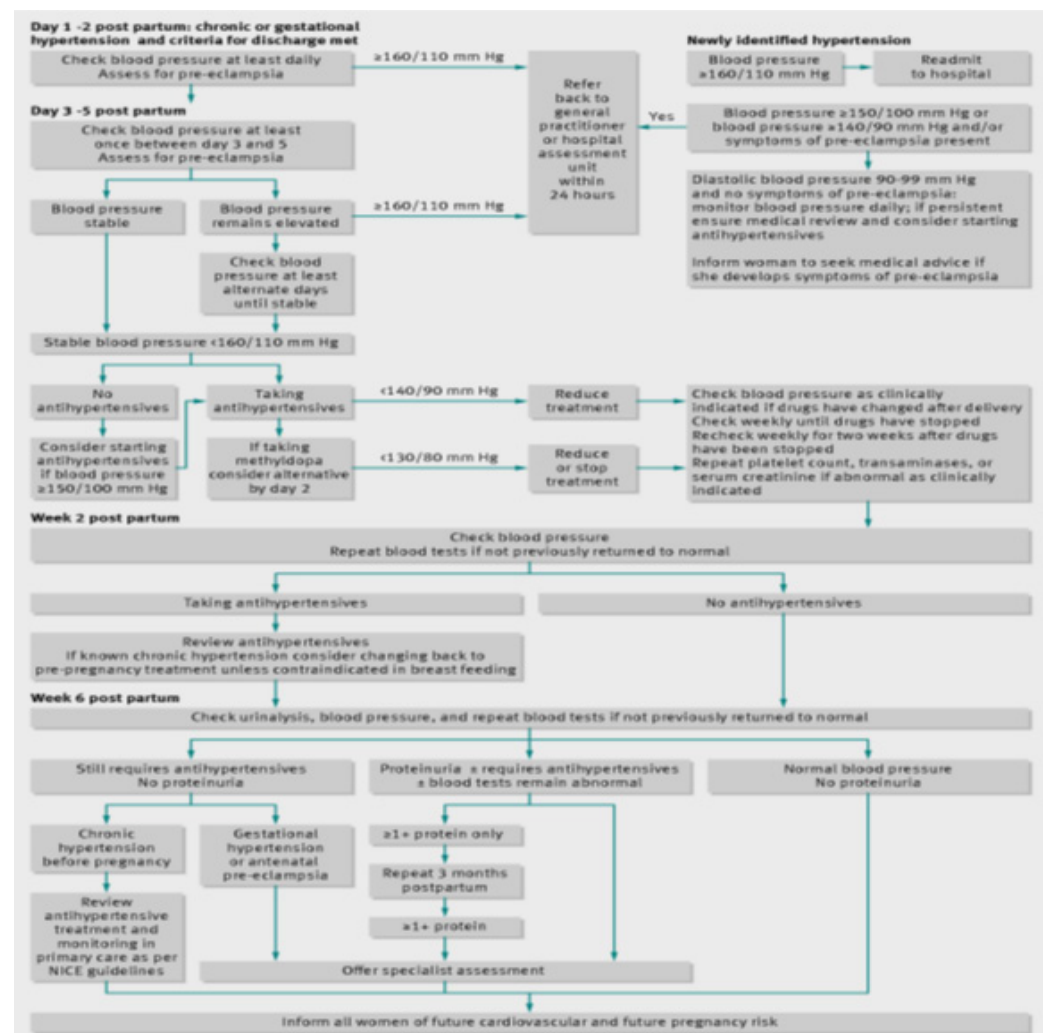

Bagan 2 Terapi Rawat Jalan pada Hipertensi Pascasalin Dikutip dari: Bramham K et al, 2013. ${ }^{1}$

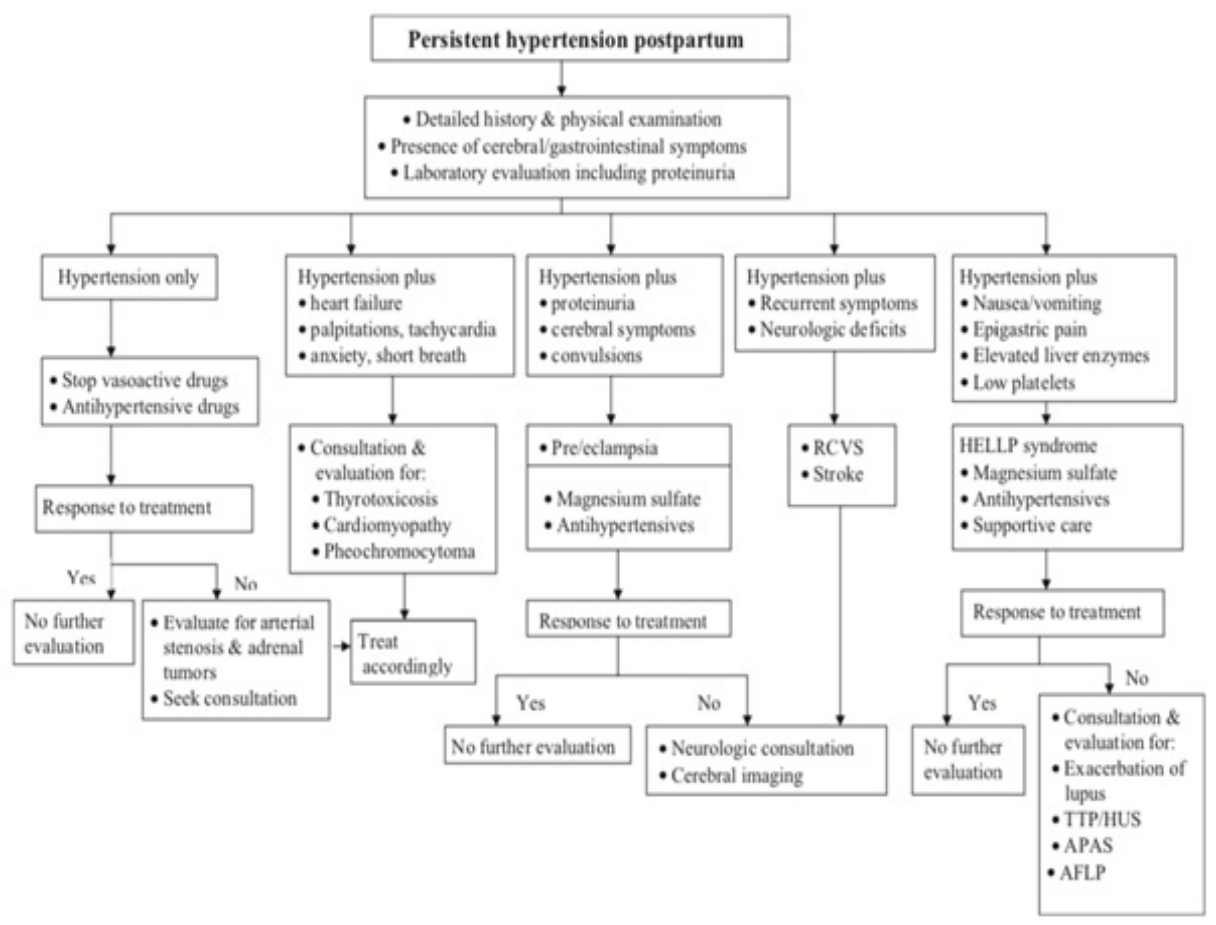

\section{Bagan 3 Rekomendasi Evaluasi dan Tatalaksana Wanita dengan Hipertensi Pascasalin}

Dikutip dari: Sibai BM, 2012. ${ }^{6}$ 
membandingkan timolol, hidralazin, dan nifedipin dengan metildopa untuk pengobatan hipertensi pascasalin ringan hingga sedang. Dua dari percobaan ini (106 wanita) tidak mencatat kasus kematian ibu di kedua kelompok. Selain itu, tidak terdapat perbedaan yang signifikan antara kedua kelompok dalam hal risiko pengobatan yang berubah karena efek samping ibu (dua percobaan, 106 wanita; RR 0,50, IK 95\% 0,05-5,30). Dua percobaan (120 wanita) membandingkan hidralazin intravena dengan nifedipin sublingual atau labetalol untuk pengobatan wanita dengan hipertensi pascasalin yang parah. Tidak terdapat kasus kematian ibu atau hipotensi ibu yang dilaporkan untuk perbandingan ini.

\section{Komplikasi}

Douglas dan Redman melaporkan tidak adanya hipertensi dan proteinuria pada $38 \%$ wanita yang mengalami eklamsia, menunjukkan efek samping ibu yang berat dapat terjadi bahkan ketika definisi klinis preeklamsia tidak terpenuhi. Gangguan janin yang tidak dikenali dapat menyebabkan peningkatan kematian janin, dan 1 dari 20 stillbirth tanpa kelainan kongenital disebabkan oleh preeklamsia. ${ }^{9}$ Riwayat preeklamsia merupakan faktor risiko independen untuk kejadian jantung dan sroke. Wanita dari studi HYPITAT yang menginvestigasi waktu optimum untuk persalinan pada wanita dengan hipertensi gestasional atau preeklamsia, pemantauan kardiovaskuler 2-5 tahun pascasalin.

Hasil ini menunjukkan bahwa hampir setengah dari preeklamsia onset dini mengalami hipertensi sebesar 39\% dan 25\% pada wanita yang mengalami hipertensi gestasional dan preeklamsia onset lambat. Selain itu, setelah 30 tahun kehamilan yang dikomplikasi oleh preeklamsia, skor kalsifikasi arteri koronaria lebih dari 50 Agatson unit sebesar 2,61 (IK 0,95-7,14) kali lebih besar daripada wanita tanpa preeklamsia. $^{9} \quad$ Sejumlah kecil wanita dengan hipertensi mengalami sakit kepala hebat atau baru (atau keduanya), gangguan penglihatan, atau defisit neurologis untuk patologi intraserebral. Faktor risiko untuk stroke dan trombosis vena serebral pascasalin termasuk usia lanjut ibu, hipertensi, seksio sesarea, gangguan cairan dan elektrolit. Sindrom vasokonstriksi serebral reversibel merupakan gangguan serebrovaskuler yang berhubungan dengan konstriksi dan dilatasi arterial multifokal yang biasanya terjadi 3-14 hari pascasalin dan berhubungan dengan sakit kepala hebat. ${ }^{1}$ Wanita yang mengalami hipertensi gestasional atau preeklamsia berisiko mengalami hipertensi dan stroke pada saat dewasa (Tabel 3). Selain itu, lebih berisiko mengalami penyakit jantung iskemik pada wanita yang mengalami preeklamsia atau PJT terisolasi, dan peningkatan kematian akibat penyakit jantung iskemik. Hubungan preeklamsia dan peningkatan risiko penyakit jantung iskemik pada usia dewasa tampak lemah. Akan tetapi, kedua kondisi ini berhubungan dengan dislipidemia, resistensi insulin, dan disfungsi endotel. Abnormalitas lipid dapat terjadi pada preeklamsia (peningkatan LDL, VLDL, asam lemak bebas, dan trigliserida) dan disfungsi endotel dapat berlanjut hingga pascasalin. ${ }^{11,14}$ Mekanisme patofisiologis yang menghubungkan preeklamsia (PE) dan hipertensi gestasional dengan Cardiovascular Disease (CVD) maternal di kemudian hari tidak diketahui dengan pasti. Kemungkinannya adalah bahwa Hipertensi dalam Kehamilan (HDK) dan CVD memiliki faktor risiko yang sama dan keduanya merupakan manifestasi dari proses patofisiologis yang sama pada waktu yang berbeda dalam kehidupan seorang wanita. Kemungkinan ini didukung oleh studi kohort besar yang telah menunjukkan hubungan yang kuat antara HDK dan sejumlah faktor risiko CVD, termasuk hipertensi kronik, diabetes melitus tipe 2 (DM), hiperlipidemia, 
dan peningkatan indeks massa tubuh (IMT). Selain itu, insufisiensi vaskular umumnya terdeteksi pada plasenta wanita dengan $\mathrm{PE}$, dan beberapa lesi ini ditandai dengan inflamasi dan makrofag yang sarat lipid yang sangat mirip dengan fitur plak aterosklerotik tahap awal. Lesi plasenta ini mungkin merupakan ekspresi awal dari kerentanan terhadap gangguan vaskuler di kemudian hari. ${ }^{15}$

Tabel 3 Konsekuensi Jangka Panjang pada Wanita dengan Sindrom Preeklamsia

\begin{tabular}{|c|c|}
\hline Organ Target & Penyakit \\
\hline Kardiovaskuler & $\begin{array}{l}\text { Hipertensi kronik } \\
\text { Penyakit jantung iskemik } \\
\text { Aterosklerosis } \\
\text { Kalsifikasi arteri koroner } \\
\text { Kardiomiopati } \\
\text { Tromboembolisme }\end{array}$ \\
\hline Neurovaskuler & $\begin{array}{l}\text { Stroke } \\
\text { Ablasio retina } \\
\text { Retinopati diabetikum }\end{array}$ \\
\hline Metabolik & $\begin{array}{l}\text { Diabetes melitus tipe } 2 \\
\text { Sindrom metabolik } \\
\text { Dislipidemia } \\
\text { Obesitas }\end{array}$ \\
\hline Ginjal & $\begin{array}{l}\text { Disfungsi glomerulus } \\
\text { Proteinuria }\end{array}$ \\
\hline $\begin{array}{l}\text { Sistem saraf } \\
\text { pusat }\end{array}$ & $\begin{array}{l}\text { Lesi substansia alba } \\
\text { Disfungsi kognitif } \\
\text { Retinopati }\end{array}$ \\
\hline Psikiatri & Skizofrenia \\
\hline
\end{tabular}

Mekanisme patofisiologis lainnya adalah penyakit kardiovaskuler di masa depan merupakan akibat langsung dari disfungsi endotel akibat HDK pasca salin.

Beberapa penelitian telah menunjukkan tanda peningkatan disfungsi endotel, kekakuan arteri, dan inflamasi sistemik hingga 8 tahun setelah kehamilan yang dipersulit oleh PE. Selain itu, wanita dengan PE mengaktivasi angiotensin II autoantibodi tipe 1 selama kehamilan yang bertahan setelah 18 bulan pasca salin. Pengikatan antibodi ini dengan reseptor angiotensin 1 telah terbukti menginduksi kerusakan endotel dan mungkin merupakan hubungan mekanik antara PE dan risiko penyakit kardiovaskuler berikutnya. ${ }^{15}$

Hipertensi selama kehamilan meningkatkan risiko gangguan spektrum skizofrenia, sementara TD yang meningkat saat tiba di ruang bersalin meningkatkan risiko gangguan mental lainnya. Beberapa penelitian sebelumnya telah mengamati bahwa preeklamsia meningkatkan risiko skizofrenia, tetapi ada juga temuan negatif.

Namun, hipertensi bahkan tanpa adanya preeklamsia dikaitkan dengan peningkatan risiko misalnya, lahir kecil untuk masa kehamilan, kehamilan dan kelahiran mati.

Satu penelitian persalinan kohort barubaru ini memperoleh hasil yang sama, yaitu hipertensi tanpa disertai preeklamsia meningkatkan risiko gangguan mental, terutama risiko kecemasan dan gangguan mood. ${ }^{16}$

\section{Rekurensi}

Kemungkinan preeklamsia berulang dipengaruhi oleh kepastian dan keparahan diagnosis klinis pada kehamilan pertama.

Dari 225 wanita dengan hipertensi selama kehamilan, $70 \%$ mengalami kekambuhan pada kehamilan berikutnya. Dalam sebuah penelitian primipara yang didiagnosis dengan preeklamsia berat, tingkatkekambuhan adalah $45 \%$. Kelompok-kelompok ini mungkin termasuk pasien dengan peningkatan tekanan darah yang belum diketahui sebelumnya atau peningkatan ginjal yang mendasari atau penyakit kardiovaskular.

Tingkat kekambuhan dilaporkan pada tahun 2006 dari penelitian terhadap 896 wanita yang pernah melahirkan di Islandia sesuai dengan kriteria diagnostik standar (Kriteria Tekanan Darah Tinggi Nasional) pada kedua kehamilan. Tingkat kekambuhan berbeda secara substansial dengan diagnosis pada kehamilan pertama (Tabel 4). ${ }^{7}$ 
Tabel 4 Tipe Penyakit Hipertensi dalam Kehamilan yang Terjadi pada Kehamilan Kedua Dibandingkan dengan Kehamilan Pertama

\begin{tabular}{|c|c|c|c|c|c|}
\hline \multirow[b]{2}{*}{$\begin{array}{c}\text { Penyakit pada } \\
\text { Kehamilan } \\
\text { Kedua }\end{array}$} & \multicolumn{5}{|c|}{ Penyakit pada Kehamilan Pertama } \\
\hline & $\begin{array}{c}\text { Hipertensi } \\
\text { Gestational } \\
\mathbf{n}=\mathbf{5 1 1}\end{array}$ & $\begin{array}{c}\text { Preeklamsia } \\
\text { atau Eklamsia } \\
n=151\end{array}$ & $\begin{array}{c}\text { Hipertensi } \\
\text { Kronik } \\
\mathbf{n}=\mathbf{2 0 0}\end{array}$ & $\begin{array}{c}\text { Superimposed } \\
\text { Preeklamsia } \\
n=34\end{array}$ & $\begin{array}{c}\text { Total } \\
\mathbf{N}=\mathbf{8 9 6}\end{array}$ \\
\hline Normal & $153(29,9 \%)$ & $63(41,7 \%)$ & $24(12 \%)$ & $2(5,9 \%)$ & $242(27 \%)$ \\
\hline Hipertensi gestasional & $239(46,8 \%)$ & $52(34,4 \%)$ & $69(34,5 \%)$ & $10(29,4 \%)$ & $370(41,3 \%)$ \\
\hline Preeklamsia & $25(4,9 \%)$ & $17(11,3 \%)$ & $6(3 \%)$ & $4(11,8 \%)$ & $52(5,8 \%)$ \\
\hline Hipertensi Kronik & $82(16 \%)$ & $16(10,6 \%)$ & $91(45,5 \%)$ & $14(41,2 \%)$ & $203(22,7 \%)$ \\
\hline Superimposed Preeklamsia & $12(2,3 \%)$ & $3(2 \%)$ & $10(5 \%)$ & $4(11,8 \%)$ & $29(3,2 \%)$ \\
\hline Semua Rekurensi & $358(70,1 \%)$ & $88(58,3 \%)$ & $176(88 \%)$ & $32(94 \%)$ & $654(73 \%)$ \\
\hline
\end{tabular}

Dikutip dari: Duhig K et al, 2018. ${ }^{8}$

\section{Pencegahan}

Bukti yang terkait dengan efek terapi obat antihipertensi rutin pascasalin dibandingkan dengan tanpa pengobatan untuk pencegahan hipertensi pascasalin pada wanita dengan $\mathrm{PE}$ antenatal dan untuk meningkatkan hasil pada wanita dengan hipertensi ringan hingga sedang diperoleh dari tinjauan Cochrane dari 8 RCT. Uji coba relatif kecil, dengan total hanya 622 wanita. Tiga uji coba (313 wanita) membandingkan kebijakan pemberian rutin obat antihipertensi oral (furosemide atau nifedipin) dengan pendekatan yang menggunakan obat antihipertensi hanya untuk hipertensi pascasalin pada wanita dengan PE antenatal. Risiko relatif tidak dapat diperkirakan untuk hasil kritis yang dilaporkan (yaitu kematian ibu, kegagalan organ ibu, efek samping ibu yang memerlukan penggantian obat dan hipotensi berat) karena tidak ada peristiwa yang dicatat dalam salah satu dari kedua kelompok setiap percobaan. ${ }^{18}$ Penelitian lainnya mencoba membandingkan efek torsemid dan placebo untuk mencegah hipertensi pasca salin persisten pada wanita yang mengalami preeklamsia. Hasil penelitian tersebut menunjukkan bahwa tidak terdapat perbedaan terhadap tingkat hipertensi $7-10$ hari atau 6 minggu pascasalin, lama rawat inap pascasalin, perawatan ulang untuk hipertensi, dan efek samping. ${ }^{19}$

Selain penggunaan medikamentosa untuk pencegahan preeklamsia pascasalin, modifikasi gaya hidup juga bermanfaat untuk mencegah penyakit kronik seperti penyakit kardiovaskuler. ${ }^{20}$

\section{Kesimpulan}

Preeklamsia yang terjadi pada pascasalin seringkali tidak terdiagnosis sehingga dapat meningkatkan morbiditas dan mortalitas maternal.

Oleh karena itu, diperlukan pemilihan antihipertensi pascasalin yang tepat yaitu berikatan kuat dengan protein dan solubilitas lipid yang rendah. Beberapa antihipertensi yang sering digunakan pada preeklamsia pascasalin, yaitu penghambat alfa atau beta, penghambat kanal kalsium dan penghambat ACE. Dengan terapi yang adekuat selama periode pascasalin, diharapkan dapat mencegah komplikasi yang dapat terjadi pada pereeklamsia yaitu komplikasi kardiovaskuler, neurovaskuler, metabolik, ginjal, sistem saraf pusat, dan psikiatri.

\section{Daftar Pustaka}

1. James D, Steer PJ, Welnder CP, Gonik B, Crowther CA, Robson SC. High risk pregnancy: Management options. St. 
Louis: ElSevier Saunders, 2011.

2. Bramham K, Nelson-Piercy C, Brown MJ, Chappell LC. Postpartum management of hypertension. BMJ. 2013;346(7897):1-9.

3. Ybarra N, Laperouse E. Postpartum preeclampsia. J Obstet Gynecol Neonatal Nurs. 2016;45(3):S20.

4. Cairns AE, Pealing L, Duffy JMN, et al. Postpartum management of hypertensive disorders of pregnancy: A systematic review. BMJ Open. 2017;7:1-14.

5. LD Levine, C Nkonde-Price, M Limaye and SS. Factorsassociated with postpartum follow-up and persistent hypertension among women with severe preeclampsia. J Perinatol. 2016;36(12):1079-1082.

6. Sibai BM. Etiology and management of postpartum hypertensionpreeclampsia. Am J Obstet Gynecol. 2012;206(6):470-5.

7. Peres GM, Mariana M, and Cairrao E.Preeclampsia and eclampsia: An update on the pharmacological treatment applied in Portugal . J. Cardiovasc. Dev. Dis. 2018, 5,3 .

8. Duhig K, Vandermolen B, Shennan A. Recent advances in the diagnosis and management of pre-eclampsia. F1000Research. 2018;7:242.

9. American College of Obstetricians and Gynecologists Bulletin. Gestacional hypertension and preeclampsia. Am Coll Obstet Gynecol. 2019;95(76):1-9.

10. Creasy RK, Resnik R, Iams JD, Lockwood CJ, Moore TR, Greene MF. Creasy \& Resnik's Maternal- Fetal Medicine: Principles and Practice, 7th Edition. Philadelphia: ElSevier Saunders, 2014.

11. James PR, Nelson-Piercy C. Management of hypertension before, during, and after pregnancy. Heart. 2004;90(12):1499-504.

12. Perkumpulan Obstetri dan Ginekologi. Pedoman Nasional Pelayanan Kedokteran. Diagnosis dan tatalaksana preeklamsia. 2016: 1-48.
13. Pregnancy HD. Committee opinion emergent therapy for severe hypertension e175. 2019;133(767):174-80.

14. Wikström AK, Haglund B, Olovsson $\mathrm{M}$, Lindeberg SN. The risk of maternal ischaemic heart disease after gestational hypertensive disease. BJOG An Int J Obstet Gynaecol. 2005;112(11):1486-91.

15. Ying W, Catov JM, Ouyang P. Hypertensive disorders of pregnancy and future maternal cardiovascular risk. J Am Heart Assoc. 2018;7:e009382.

16. SuvisaariJM, Taxell-Lassas V,Pankakoski M, Haukka JK, Lonnqvist JK, and Hakkinen LT. Obstetrics complications as risk factors for schizophrenia spectrum psychoses in offspring of mothers with psychotic disorder. Schizophr Bull. 2013;39(5): 1056-66.

17. Cunningham F. Gary, Kenneth JL, Steven LB, Jodi SD, Barbara LH, Brian MC, et al. Williams obstetrics. 25 th edition. New York: McGraw-Hill Education, 2018.

18. World Health Organization. WHO recommendations for prevention and treatment of pre-eclampsia and eclampsia. 2011: 1-38.

19. Viteri OA, Alrais MA, Pedroza C, Hutchinson M, Chauhan SP, Blackwell $\mathrm{SC}$, et al. Torsemide for prevention of persistent postpartum hypertension in women with preeclampsia. Obstet Gynecol 2018;132:1185-91.

20. Kamravamanesh M, Kohan S, Rezavand N, Farajzadegan Z. A comprehensive postpartum follow-up health care program for women with history of preeclampsia: Protocol for a mixed methods research. Reprod Health. 2018;15:81. 